\title{
US-ROMANIAN STRATEGIC PARTNERSHIP - PAST, PRESENT AND FUTURE
}

\author{
Captain Alexandru CRISTIAN, Ph.D. ${ }^{637}$
}

\begin{abstract}
Based on 140 years of diplomatic relations made permanent and on almost 180 years of trade agreements, the US-Romanian relations evolved depending on the historical circumstances. Relations have grown stronger and more complex, to become permanent and eventually instrumentalized. The emergence of new diplomatic cooperation tools meant the professionalization and institutionalization of US-Romanian bilateral relations. July 11, 1997 - the launching date of the Strategic Partnership - is a historical turning point in the relations of the two countries, which has been beneficial for both stakeholders.
\end{abstract}

Keywords: Strategic Partnership; United States of America; Romania; bilateral relations; pillars; trust; loyalty; cooperation.

\section{EVOLUTION OF THE US-ROMANIAN BILATERAL RELATIONS - A BRIEF LOOK}

Based on 140 years of diplomatic relations made permanent and on almost 180 years of trade agreements, the US-Romanian relations evolved depending on the historical circumstances.

We can state that both time and history left marks on the development of the US-American bilateral relations. These relations can be considered according to several periods in line with the historical circumstances of those times. Some chronological classification can highlight the historical trend of US-American relations.

The first or early period can be considered between 1843 and 1880.1843 is the year when a first American commercial ship reached the Romanian harbor of Galați. Back in those times, the Unite States were undergoing territorial and economic spread to the fullest, while trade was a fundamental pillar in the progress of the American state. The conquest of the Rocky Mountains meant the rise of a new nation ${ }^{638}$.

The second period can be placed between 1880 and 1940 - the period when the US-American relations got official and expanded. There are two years of utmost importance during this period: 1880, when the bilateral relations became official by appointing the first American diplomatic representative to Romania, and 1918, when the Romanian Legation was established in Washington D.C. We

\footnotetext{
${ }^{637}$ Captain Dr. Alexandru Cristian, Ph.D. is historian, member of National College of Defense Staff.

${ }^{638}$ Dumitru Vitcu, Relațiile Româno-Americane timpurii, Editura Albatros, București, 2000, pp.44-46.
} 
must emphasize that during the World War One, Romania and the United States of America were allies without being bound by any official legal deed, such a treaty or a pact. We were Allies without Alliance, according to historian Ion Stanciu.

1940 marked the interruption of the bilateral relations because of the state of war. The relations were suspended until the communist regime reopened the Romanian legation in the United States and acknowledged communist Romania by appointing a diplomatic representative on 28 July 1947 - Rudolf E. Schoenfeld.

The third period (1947-1989) was marked by the most significant challenges for the bilateral relations. In 1964, both states upgraded their legations to be embassies. The relations between communist Romania and the United States were regarded as a paradox, a state in the shadow of Moscow having a normal, pretty good relation with the latter's great enemy. Both researchers called the 1967-1975 period an adultery in the communist family. Those years were symbolized by the outstanding activity carried out by Ambassador Corneliu Bogdan. ${ }^{639}$

After the fall of the communist regime, our country wanted to erase the past and took a big step towards the future, which seems to give realistic hopes to the Romanian population. We had a historical chance to join the Euro-Atlantic area. The 1995 Snagov Declaration was a historical milestone as all politicians federated around a national ideal, which is having the country accepted in the Euro-Atlantic area.

The period subsequent to the December 1989 revolution of the USRomanian bilateral relations was marked by goals such as trust-winning and setting more effective cooperation. 1997 is a symbol for the Romanian foreign politics after 1989. The Strategic Partnership between the United States and Romania was signed on 11 July 1997. An event to mark the entire history of USAmerican bilateral relations. Our countries have been allies with no alliance, had complex relations during the communist era, but with the launch of this Strategic Partnership we officially became partners and established cooperation at various levels.

The Joint Declaration of the Strategic Partnership for the $21^{\text {st }}$ century between Romania and the Unites States of America was signed on 13 September 2011. A legal binding document to cement the bilateral relation by undertaking cooperation fields between the two countries in the $21^{\text {st }}$ century. Moreover, the Joint Statement of the Implementation of the Strategic Partnership for the $21^{\text {st }}$ century between Romania and the United States was launched on 26 September 2016 in Washington D.C.

639 Mircea Răceanu, O cronologie comentată a relațiilor româno-americane, Editura Silex, București, 2005, p.110. 
US-Romanian relations have been evolving according to historical time. As unexpected as it is, full of uncertainty, history sometimes had (the first and last) word to say in these countries' bilateral relations.

\section{THE EVOLUTION OF THE US-ROMANIAN STRATEGIC PARTNERSHIP}

How can the Strategic Partnership be defined? A generic abstract definition would be that the partnership is a foreign politics deed, a paper of intent with no legal grounds as it is the case with treaties or pacts. A partnership is the intention of some states to strengthen bilateral relations in certain fields, which are provided in the document in most cases. The emergence of strategic partnerships is a factor rendering foreign politics more technical, like a niche document, provided a treaty is a broader and more general a strategic partnership based upon certain fields.

The Strategic Partnership emerged as a sequel to the Romanian foreign politics subsequent to 1989 . We must state our country was the first EasternEuropean country to sign the Peace Partnership on 26 January $1994 .{ }^{640}$

After the Madrid Statement and the US president Bill Clinton's visit which emphasized the emergence of the Strategic Partnership, the deputy Secretary of State of the United States, M. Grossman, established the fields of interest of the partnership the following year. ${ }^{641}$

From 1997 until 2011, the Strategic Partnership was characterized by the development and deepening of the bilateral relations. We divided this period into two because the Joint Statement on the Strategic Partnership is to be signed in 2011. Our country joined NATO in 2004.

The Strategic Partnership was developed around military cooperation, regional security cooperation, and developing joint mechanisms regarding nonconventional threats and risks. The Strategic Partnership also meant the emergence of new institutions and mechanisms in Romania. I mean the establishment of the National Anticorruption Prosecutor's Office (currently named the National Anticorruption Directorate), the establishment of the National Terrorism Prevention and Fighting System, the national authority of which is the Romanian Intelligence Service, according to the Law no. 535/2004. The Status of Force agreement or the Access Agreement was signed in 2005, allowing to settle American military contingents on the territory of the country. In 2006 Romania was the first East-European country to sign an agreement to receive an American

\footnotetext{
${ }^{640}$ Alexandru Marian Crengăniş, Parteneriatul Strategic România- S.U.A, scurt istoric și evoluție, online https://www.casamariinegre.ro/studii/geopolitica/182/parteneriatul-strategic-romania-sua-scurt-istoric-sievolutie, accessed on 10.05.2021, 11:30.

${ }^{641}$ See Nicolae Toboșaru, Parteneriatul Strategic dintre România și Statele Unite ale Americii, Fragmente de istorie in interviuri, Editura Presa Universitară Clujeană, Cluj-Napoca, 2009.
} 
military contingent on Romanian soil. Another bilateral agreement was the one in the field of international criminal justice. ${ }^{642}$

We also have to mention the Agreement concluded between Romania and the United States regarding the activities of the US forces sent on the territory of Romania, an agreement signed on 6 December $2005 .{ }^{643}$

A Partnership Committee for Strategic Partnership was also established during the years 1997-2011, a structure managed by the Ministry of Foreign Affairs and by the Department of State.

During the first years, the Partnership grew, but was not institutionalized and it was not marked by tight cooperation in other fields such as the economic, social, or economic one. ${ }^{644}$

The US democratic administration started in 2009 wished to revive the US strategic partnerships worldwide, and initiated talks to strengthen the Strategic Partnership between Romania and the United States. The geopolitical and geostrategic purpose was to locate an air defense system against ballistic missiles in Europe. Such purposes were determined by the worldwide war against terrorism, and by the momentum gained by the Russian Federation as a power. Geopolitics and geography brought both states even closer to each other.

\section{THE JOINT STATEMENT ON THE US-ROMANIAN STRATEGIC PARTNERSHIP FOR THE $21^{\text {ST }}$ CENTURY}

The emergence of the Joint Statement was boosted by external objective historical factors and by the intrinsic American geopolitical thinking, besides Romania's need for strategic security. The statement arose around the willingness to develop some complex defense system against ballistic missiles in Eastern Europe.

Installing US contingents at the Mihail Kogălniceanu base in Constanța was the start of this complex military and security cooperation.

The Joint Statement was signed on 13 September, in 2011. This document has in view several goals to deepen bilateral cooperation.

The agreement signed by Romania and the United States to install a US defense system against ballistic missiles in Romania is a legal deed which helped build and render the military base in Deveselu, Olt county operational. This agreement, signed in 2016, was concluded for an unlimited period, and was followed by more technical agreements pertaining to military cooperation. The military base was built between 2011 and 2016, to become operational in 2016 as the Military Base no. 99 in Deveselu. The Base thus became a key stage in the

\footnotetext{
${ }^{642}$ Alexandru Cristian, Enciclopedia Relațiilor Româno-Americane, baza de date online, https://www.usro.ro/10ani-de-la-declaratia-comuna-privind-parteneriatul-strategic-pentru-secolul-xxi-intre-romania-si-statele-unite-aleamericii/, accessed at 10.05.2021 11:35.

643 Ibidem.

${ }^{644}$ Nicolae Toboșaru, The Romanian-US Strategic Partnership: History and Geopolitical Importance, Kindle Edition, Amazon, 2016, pp. 195-200.
} 
development of the US anti-missile defense system on the European soil, called the European Phased Adaptive Approach. ${ }^{645}$

The military base in Deveselu was included in the N.A.T.O. Strategy on developing a defense system against ballistic missiles. This base, along with the facilities in Mihail Kogălniceanu, is a new fundamental pillar in preserving security in the Wider Black Sea Area. The Joint Statement also provides the establishment of a Task Force aimed at strengthening cooperation in fields such as economy, energetic security, the visa issue, and other social and economic matters.

The Joint Statement on Implementing the US-Romanian Strategic Partnership for the $21^{\text {st }}$ century was signed on 26 September 2016 in Washington D.C. The new directions of action contemplated by the Romanian counterpart are developing some sound economic cooperation, and eliminating visas for Romanian citizens. As far as access to the Visa Waiver programme is concerned, the US expressed their support for Romania, yet the issue raised was developing an effective counterterrorism system at the national level, and reducing the refusal rate for providing visas for Romanian citizens. Such issues are not impossible to overcome.

The Strategic Partnership is one of the three pillars of the foreign policy of our country, as well as its status of European Union and NATO member. The Strategic Partnership is an effective foreign politics tool, which is sustainable and aimed towards a crucial, important field, i.e. the military and national security dimension of both states. Because the Strategic Partnership strengthens, at various levels, the national security of Romania and of the Unite States. More than two decades of military and security cooperation have passed, which made our bilateral relation stronger, but it should be taken to the next level. Institutionalizing the Strategic Partnership in a legal deed or a foreign politics tool must be seriously analyzed and taken into account. ${ }^{646}$

\section{PILLARS OF STRATEGIC PARTNERSHIP - NEW DIMENSIONS OF COOPERATION}

Throughout the human history, the nations have collaborated, cooperated, and collided. History books teach us the underlying mechanisms which allowed all this to happen. There are several answers, varying from resources to the thirst for power and influence.

The Romanian and the American nations were established on absolute, unattackable values, such as the wish to be free and to accomplish the fate of their nation. Of course, history, geography, social and cultural factors underlay

\footnotetext{
${ }^{645}$ Cristian Alexandru, Enciclopedia Relațiilor Româno-Americane, https://www.usro.ro/10-ani-de-la-declaratiacomuna-privind-parteneriatul-strategic-pentru-secolul-xxi-intre-romania-si-statele-unite-ale-americii/, accessed at 10.05.2021 11:35.

${ }^{646}$ The National Defense Strategy for the period 2020-24, issued by the Presidential Administration, approved by the Supreme Council of National Defense on May 27, 2020, by the Parliament on July 1, 2020.
} 
different, yet mostly similar evolution. As a matter of fact, any group of people wants to have an identity which evolves and turns into a people, and ultimately into a nation endowed with historical and meta-historical conscience.

The US-Romanian Strategic Partnership was a geopolitical time which deeply marked the evolution of both peoples, as well as that of Europe as a whole. Europe has always been related to the US; History is a witness in this respect. The shift occurring at that point meant so much for our nation, and it has an impact difficult to quantify at the present. The wish to be present in a universe only known from written documents helped the American people dearly accept this basically geopolitical idea.

The 141-year bilateral relations (counting 117 years at that time, on 11 July 1997), have evolved and culminated in 1997. Due to this Partnership, our country was finally placed on the map of the democratic world. A country extremely well placed from a geographical standpoint, having significant resources, as well as a particularly interesting social dynamism.

For this Partnership to resist and to evolve towards institutionalization, by signing an alliance treaty it needs to rely on a few fundamental pillars. We identified three pillars difficult to measure and to evaluate, yet which underlie every human relation in general, and good relations between states in particular. ${ }^{647}$

\section{Trust}

Loyalty

\section{Cooperation}

Trust as a first definition means trusting someone's honesty, relying on someone, according to the Romanian Language Dictionary. In English, trust means believing that someone is good and honest to you, and does not hurt you, as the Cambridge dictionary of the English Language shows to us. Both states need to rely on each other and have mutually beneficial relations so that the purpose is reached in a holistic and fully realistic way. We must trust the US; the US must trust us. Any kind of relation between nations and countries falls apart without trust. Trust is the first step to build and strengthen any bond.

Loyalty is defined as the existence of sincerity in a relation. Being honest, telling what one believes, feels, and knows in all trust. In English, loyalty means being steady in one's friendship, and not changing this feature depending on other unpredictable events or other factors getting involved in one's direct relation. Any bilateral relation needs to be characterized by loyalty as well, which means a high level of friendship and trust. We need to be loyal to the United States, while the United States need to be loyal to us. Thus, we can overcome any challenge together, depending on the historical time. The pandemic gave us an important proof of loyalty when our two countries supported and helped each other.

\footnotetext{
${ }^{647}$ Alexandru Cristian, op.cit.
} 
Cooperation means working along - team work, both being grounded on the same values and norms, according to the Romanian Language Dictionary. Cooperation in English means acting or working together to reach a common goal or to help someone who requires this from one. Cooperation needs to be sincere, honest, and rely on trust and loyalty - the only way for the goal to be reached. In the US-Romanian Strategic Partnership, cooperation in the field of national security has been excellent, even outstanding. Cooperation must be also pursued in the economic, cultural, and scientific fields. ${ }^{648}$

These three pillars must be the starting point for strengthening the Strategic Partnership between Romania and the United States for it to get more in-depth, to be institutionalized, and turn into an alliance treaty between the two countries. Why do we need this Partnership and why do we need an alliance? History has already answered these questions: nobody can survive alone in this world. Any country needs to get closer to states sharing their own values. ${ }^{649}$

\section{FROM PARTNERSHIP TO A STATEMENT, TO A TREATY? LOOKING TO THE FUTURE}

Relations between countries evolve themselves alongside those of the nations. The evolution of the bilateral US-Romanian relations shows us that we can have excellent relations without formalizing such relations as official legal deeds.

Cooperation in the field of intelligence, as well as terrorism, was extremely beneficial to our country and it was another solid pillar of the Strategic Partnership. It is necessary to enlarge the Strategic Partnership to other fields of cooperation (economic, cultural, scientific, and social) to develop our country and enhance its strategic capacity. It is also core to strengthening the national security of our country, and to designing some steady climate in the Enlarged Black Sea Area, named the Enlarged Black Sea Region by other authors.

We have had trading agreements, we set our bilateral relations on a permanent route, we have been allies without an alliance (according to Ion Stanciu's definition) during the First World War ${ }^{650}$, we had smooth relations during the communist era, and everything reached a peak with the Strategic Partnership. Subsequent to the Strategic Partnership was signed the Joint Statement, which made our Partnership even stronger. The historical event rationale shows us we are heading towards another stage of our cooperation, i.e. that of formalizing and institutionalizing the Strategic Partnership. At the present, almost a quarter of a century later, and a decade after the Joint Statement, I strongly believe the US-Romanian bilateral relations should take the form of negotiation, signing, and ratifying a treaty.

\footnotetext{
${ }^{648}$ Ibidem.

${ }^{649}$ Ibidem

${ }^{650}$ Ion Stanciu, Aliați fără Alianță, Editura Cetatea de Scaun, Târgoviște, 2000.
} 
A sound cooperation and alliance treaty between the US and Romania would be paramount for the good bilateral relations, as well as a persuasive message for our partners in the European Union and the North Atlantic Treaty Organization. While the Russian Federation developed A2AD (Anti-Access/Area Denial) mechanisms by building strong capabilities in the Black Sea, our country cannot respond but by making the US-Romanian bilateral relation stronger, and by respecting its commitments within the EU and N.A.T.O.

A cooperation and alliance treaty to formalize cooperation and exchange in fields such as education, research, ecology, tourism, and entrepreneurship, along excellent military and strategic relations between the two countries. Of course, it takes much time and effort to accomplish this, which in my opinion, is possible and is the outcome of the commitment of the entire administrative apparatus of our country, as well as by the US administration.

This is neither prognosis, nor a forecast. This is an analysis taking into account the event-related rationale of History which can be overturned by unpredictable events.

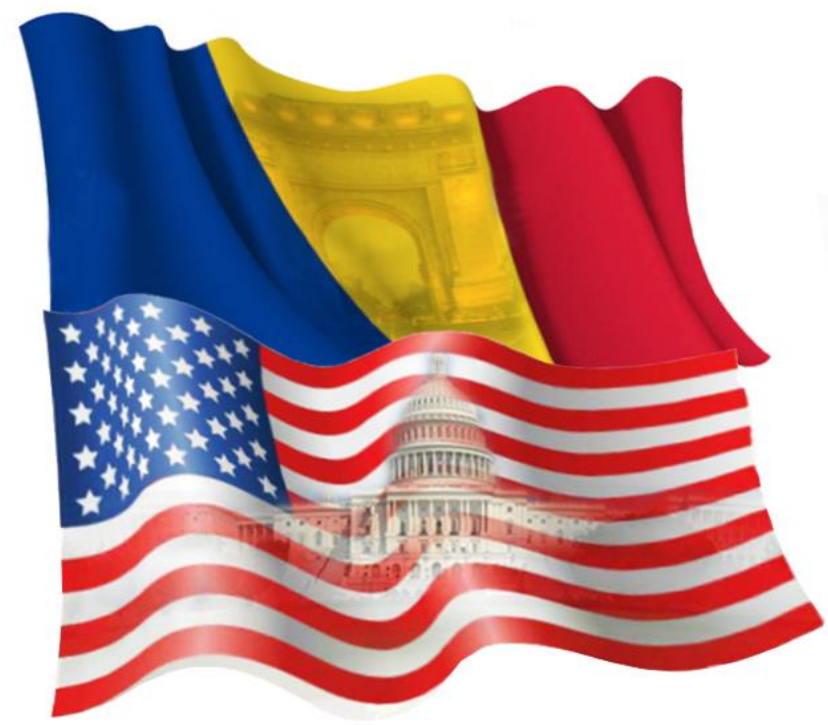

\section{BIBLIOGRAPHY}

\section{Books and Studies}

- Ciochinaru Ș., România - Statele Unite ale Americii De la Războiul Rece la Coaliția Antiteroristă, Editura Alutus, Slatina, 2007.

- Dumitru V., Relațiile Româno-Americane timpurii, Editura Albatros, București, 2000.

- Harrington J., Courtney J, Bruce, Relații româno-americane, Editura Institutul European Iași, 2002. 
- Răceanu M., O cronologie comentată a relațiilor româno-americane, Editura Silex, București, 2005.

- Stanciu I., Aliați fără Alianțăa, Editura Cetatea de Scaun, Târgoviște, 2000.

- The National Defense Strategy for the period 2020-24, issued by the Presidential Administration, approved by the Supreme Council of National Defense on May 27, 2020, by the Parliament on July 1, 2020.

- Toboşaru N., Parteneriatul Strategic dintre România şi S.U.A., Editura Presa Universitară Clujeană, Cluj-Napoca, 2009.

- Toboșaru N., Parteneriatul Strategic dintre România și Statele Unite ale Americii, Fragmente de istorie în interviuri, Editura Presa Universitară Clujeană, Cluj-Napoca, 2009.

- Toboșaru N., The Romanian-US Strategic Partnership: History and Geopolitical Importance, Kindle Edition, Amazon, 2016.

\section{Online sources}

- Crengăniș A.M., Parteneriatul Strategic România- S.U.A, scurt istoric și evoluţie, https://www.casamariinegre.ro/studii/geopolitica/182/parteneriatulstrategic-romania-sua-scurt-istoric-si-evolutie

- Cristian A., Enciclopedia Relaților Româno-Americane, online, https://www.usro.ro/10-ani-de-la-declaratia-comuna-privind-parteneriatulstrategic-pentru-secolul-xxi-intre-romania-si-statele-unite-ale-americii/

- Cristian A., 140 years of US-Romanian Relations, Amazon Edition, https://www.amazon.com/140-Years-US-Relations-Partnership/dp/ B088JFH5Z5 